The Social Sciences 14 (12): 399-405, 2019

ISSN: $1818-5800$

(C) Medwell Journals, 2019

\title{
Implementation of Policy on Increasing Food Security in North Bolaang Mongondow Regency of North Sulawesi Province
}

\author{
Mohamad Hidayat Panigoro, JuandaNawawi, Chalid Imran Musa and Asna Aneta \\ Public Administration of Universitas Negeri Makassar, \\ Jln. Bonto Langkasa Kampus Gunung Sari Baru Program Pascasarjana, \\ 90222 Makassar, South Sulawesi Province, Indonesia
}

\begin{abstract}
In the context of human life is needed the food source. However, today the scarcity often appears in various places in Indonesia. Therefore, the regional government by the mandate of decentralization should be able to create a program for the empowerment of farmers to realize food security. This research used qualitative research method with the clear approach through observation interview and documentation. Data analysis model was Strauss and Corbin data analysis, model. The result of this research was about the implementation of policy of increasing food security in North Bolaang Mongondow regency was more optimal in realizing food security. There is no significant gap between the production with the potential of a food crop where production was better and improved. It because farmer's knowledge and skills in cultivating were increasing. The main contributing factor to the success of increasing food security in North Bolaang Mongondow regency was the progress of the program with support from the regional government and subsidy and seed support. The obstacles come from the problem of the low quality of human resources and the limitations of agricultural tools. It was necessary for synergy among farmers, communities and governments to jointly support the farmer empowerment program to improve food security.
\end{abstract}

Key words: Implementation, policy, food security, empowerment, human life, production

\section{INTRODUCTION}

The importance of the role of food security in realizing robust and vigorous national resilience is reflected in the establishment of food security development in the fifth priority of national development of the government of the republic of Indonesia as stipulated in the FSAMA. (2010) and RPJMD North Sulawesi Provincial Government in 2011-2015. The priority of this food security development also confirmed in RPJMD of North Bolaang Mongondow regency government 2011-2014. Development of food security 2014-2020 is focused on increasing food availability, stabilizing food distribution and accelerating food diversification by local characteristics by improving food security and nutritional quality through cooperation with various stakeholder interests both at the center and in the regional (Anonimous, 1998).

Implementation of food security development program is implemented by taking into account sub-sub-system of food security that is through effort to increase production, availability and handling of food insecurity, stabilization of distribution and food reserve and improvement of food consumption and safety quality. Ultimately, the main actors in the field for food supply are farming communities, as the implication is that farmers and rural dynamics should always be considered as one of the determinants of the effectiveness of legal instruments and financial instruments in the region. A comprehensive and profound understanding of the farmer's life-elves is a key requirement to cultivate community initiatives as subjects in the control of productive agricultural land conversion. In this regard, the design of implementation policies and strategies in the regions will be easier to formulate if farmers are involved in any formulation and implementation of policies related to food security.

Similarly in North Bolaang Mongondow regency as one of the new areas in North Sulawesi province and according to the objectives of the expansion of the region itself to build an area aimed at improving the welfare of the community. The government of North Bolaang Mongondow regency develops the vision, mission, objectives and targets as articulation manifestations of the aspirations of the people who are compiled based on the programs and activities of each field affairs.

Considering the condition and how the role of North Bolaang Mongondow regency government to observe the importance of food security in the region and supported by the potential and carrying capacity. North Bolaang Mongondow regency as a region whose majority of the

Corresponding Author: Mohamad Hidayat Panigoro, Public Administration of Universitas Negeri Makassar, Jln. Bonto Langkasa Kampus Gunung Sari Baru Program Pascasarjana, 90222 Makassar, South Sulawesi Province, Indonesia 
live population dependence from agricultural products need attention, policy on food security in policy products, implementation, monitoring and evaluation of the final objectives. To be achieved through the food security policy which encourages and strengthens the commitment of local governments to promoting in particular, the development of the agricultural sector itself. In this perspective, the development of the agricultural sector is more specifically manifested in the form of a program policy that supports the enhancement of food security. As outlined in the regional regulation No. 4 in 2009 on medium term development plan (RPJMD) of North Bolaang Mongondow regency which is continuously annually annexed in the Regional Regulations on Regional Budget (APBD) from 2008-2013.

As an agrarian area, food security development opportunities in North Bolaang Mongondow regency are open and promising where the possibilities are: by utilizing the current technological advances the data/information can be accessed quickly, accurately and easily by the users. The availability of food data and information is very necessary in formulating food security planning, so that, the planning of food sector is more focused. As an agricultural area of North Bolaang Mongondow regency has relatively rich and diverse natural resources that can be managed to build food security.

Various food sources and local food can be developed to meet the food needs of the community. The participation of the food processing industry is growing, so that, it can realize the condition of the society that is conducive in diversifying food consumption. As a positive impact on the community education process, the level of public awareness of security, quality, food and nutrition is increasing so that people's awareness to consume the right amount of food and balanced nutrition. Regional autonomy provides opportunities for policy and implementation of the development of food security based on natural resources and local culture.

\section{Literature review}

Implementation of public policy: The general policy according to Zainal (2006) can be distinguished in three levels: General policy which is a policy that guides or guides implementation either positive or negative nature covering the whole region or Agency concerned. Implementation policy is a policy that describes the public policy. To the middle level, government regulations on the implementation of law. Technical policy, operational policies that are under implementation policy.

According to Edwards (1980) the implementation of public policy is a process that lies between the stage of policy formulation and the stage of evaluation or policy influence. Thus, understanding what exactly happens after a program is formulated as a matter of implementation.
Policy implementation is the unifying process of various elements to get the results of the programs that have been made; the process is flexible to achieve adjustments between items that support the implementation process to achieve the program objectives.

Implementation is the effort of some policy makers to influence the behavior of street level bureaucrats to service or manage the behavior of one or more target groups. It is hoped that the implementation of the policy has a real impact on people. It is not only the behavior of the administrative bodies that are responsible for the implementation of the program and the compliance of the target group but also the direct and indirect network of political, economic, social forces involved In program implementation. Implementation of the program is influenced by not only those mandated by legislation but also by the pressure of interest groups by the legislator's intervention and by various other factors in the political environment (Thomas, 1987).

Meter and Horn (1975) argued that policy implementation is: that policy implementation is an activity in the policy process that includes various actions, both done by the government and community groups directed to achieve the goals and objectives that have been set. The point is that the decisions that have been formulated are transformed into actionable actions to achieve the goals and objectives established by the decision maker. Based on several definitions mentioned above, it is concluded that implementation is a process involving some sources including human, fund and organizational capability, both by the government and private (individual or group). From some of these opinions can be described the main elements of the process of policy implementation as follows:

The process of policy implementation is a series of follow-up activities (after a program or policy set) which consists of decision-making, strategic and operational steps taken to realize a program becomes a reality. The actual implementation process can succeed or fail to achieve the objective (outcomes) because in the process also play or involved various elements that support or hinder the achievement of program targets.

The implementation process at least there are three essential elements, namely: the existence of programs or policies implemented, target groups, i.e., community groups that are targeted and are expected to receive benefits from the program (Smith, 1994). The implementing elements, whether organizations or individuals, responsible for the management, implementation and oversight of the implementation process. A model for policy implementation has been developed by Charles (1996) suggests, implementation is an activity intended to operate a program.

According to Charles (1996), to operate the program, there are 3 activities that need to be done namely: 
Organization, as an activity related to the establishment or rearrangement of resources, units and methods to make the program run. Then, to achieve the policy objectives, the government must take action in the form of pooling resources and manage those resources. Interpretation interpreting the program to be a concrete and clear and workable plan. In the implementation process, the government bureaucracy that acts as an implementing organization needs to interpret the program to be more operational and ready to be implemented in this case the program is formulated as a project, so that, the executors in the field can act according to the project plan. The application is a fixed provision for the service to achieve program objectives. With the deployment of all resources through this application, it is expected that a response from the target group or the environment will arise whether or not to accept the implementation and the outcome of the policy.

The fact that encountered is the inconsistency in interpreting causing problems cannot be solved. Various programs have been implemented to apply a policy but those programs have failed because the implementers did not learn from previous program failure experience, so, the automatic implementation of the policy also failed. One reason is that the program reflects more of a consensus and ignores the real belief in the program's success. Food security concept food security is a perception of the relationship situation between people with the need for food. Food is a commodity commonly eaten by humans to meet the needs of his life.

Up to now, the concept has undergone many changes which occur at the global, national, household and individual levels, from a food perspective as a basic need to a livelihood perspective and from objective indicators to subjective perceptions (Lassa, 2009). Food security has three dimensions: the availability of adequate quantities of food in appropriate quality and provided through domestic or imported production; accessibility of households and individuals to food suitable for a nutritious diet; and affordability Individuals to consume food according to socioeconomic conditions based on their cultural background and their respective choices. While Agus and Pasandaran (1990) suggest perceptions about food security. It may be more obvious when approached from the opposite side by imagining situation of food insecurity.

The food situation in a region is vulnerable if there is a group of people in the region having difficulties in obtaining basic food needs for their livelihood. Food in the concept of food security should be interpreted as the staple food of a society discussed, not all food alternatives. What needs to be considered in the analysis of food security is the relationship between humans with humans to food. Food consumed $\mathrm{X}$ today is food that cannot be consumed by others and vice versa
(Agus and Pasandaran, 1990). Therefore, food security is a product of the relationship between people and people and not people with food. Food security is always social context; it is based on the condition of food security needs to be achieved for reasons: the situation of food security by itself is a safe situation. Food safety is needed especially in the face of uncertainty elements of food production in the future.

Maltusians argue that famine and food insecurity is a matter of production and availability only but this is denied by some food experts among Dreze and Amartya (1989) who argue that food and hunger insecurity occurs in the absence of access to food (entitlements failure). In the economic structure in which the process of transactions (exchange) is a medium of food flow from one party to another, food security is conditioned by factors that determine the interconnection between people and people through the transaction process Agus and Pasandaran (1990). These factors include: ownership of something including labor or a good (money) that can be exchanged for food; natural disasters that could destroy agricultural production such as drought, flood or pest attacks; political instability; changes to other changes outside the food system.

Since, the 80s the discourse on food security has been dominated by food entitlements, risks and vulnerabilities. According to Maxwell (1996) and Lassa (2009) there are at least four elements of sustainable food security, namely: food sufficiency defined as the number of calories needed for active and healthy life; access to food, defined as entitlements entitlements) to produce, buy or exchange (exchange) food or receive as a transfer; resilience defined as a balance between vulnerability, risk and social safeguards; the function of time when food security can be chronic, transitional and cyclical. Slightly different from Timmer (2005) food security exists when all people at all times have physical and economic access to adequately meet their dietary needs in life for production and health.

According to Timmer (2005), food security has three dimensions: the availability of adequate nutrition in the sense of good quality and supplied through domestic and imported production. Access by households and individuals to obtain food properly, utilization food through adequate food, clean water, sanitation and health care. The opinion expressed by Timmer (2005), also supported by Hadar (2008) which suggests that the requirements of public food security are not only in the procurement of food but accessibility to food for those who are hungry.

Food security components and indicators: According to Suryana (2002), food security is the realization of the work of a food economy system consisting of three subsystems namely subsystems of supply, distribution and 
subsystems of consumption interacting continuously. The development of the supply subsystem includes the regulation of the stability and sustainability of food provision, both domestically, backed up and from abroad. The development of distribution subsystems includes arrangements to ensure the physical and economic accessibility of the population to inter-regional and inter-period food as well as strategic food price stability. The development of the consumption subsystem includes the management of food at the regional and household level to ensure each obtains food in quantity, nutritional quality, security, diversity and affordability according to his needs and preferences.

Maxwell and Smith (1992) say that food security indicates an individual's access to meet food needs at all times. It means that food security has four dimensions: food sufficiency indicated by the level of energy sufficiency for active and healthy living; access to food which means the ability to produce buy food or receive food; guarantees, namely the guarantee to obtain adequate food and time, i.e., the guarantee to obtain sufficient food in a sustainable manner.

Suryana (2002) argued that the success of the three subsystems of food security need to be supported by input factors in the form of facilities infrastructure and institutional production, distribution, marketing, processing and so on. Besides, it should also be supported by supporting factors such as policies, regulations, guidance and supervision of food. Food security is implemented by many actors such as producers, processors, marketers and consumers who are fostered by various sectoral, sub sectoral agencies and influenced inter-regional interaction. The expected output of food security development is the fulfillment of human rights for food, the increasing quality of human resources, the increasing of economic resilience and national resilience.

According to Soetrisno, two important components of food security are the availability and access to food. The level of food security of a country/region can be sourced from the ability of production, economic ability to provide food and conditions that distinguish the level of difficulty and barriers to access food. Furthermore, Sawit and Ariani stated that the determinants of food security at the household level are access to food, food availability and risks associated with access and availability of food. Food security is produced by a food system consisting of three subsystems, namely: availability of food in quantities and types sufficient for the entire population, a smooth and uniform distribution of food and food consumption of each that meets the nutritional adequacy and health principles (Nugroho, 2006).

Food availability is built through increased domestic production capability, improved reserve management and imports to fill the gap between production and demand. Food distribution is undertaken to ensure the stability of food supply and food prices between regions and time, enabling communities throughout the country to access food physically and economically. Food consumption is built by increasing the ability of households to access adequate food through their productive economic activities, either from food agribusiness or from other income-generating businesses to purchase food, as well as increased knowledge and awareness in consuming diverse, nutritious and balanced foods. As one of the subsystems of food security system FAO prioritizes food supply system with five characteristics that must be fulfilled, namely:

Capacity: Able to produce, import and store staple food in sufficient quantity to meet the needs of all the population food sufficiency.

Equity: Able to distribute the staple food, so that, it is available within reach of the whole family.

Self-reliance: Able to guarantee the provision of basic food by relying on its strength, so that, the threat of market fluctuation and international political pressure.

Reliability: Able to reduce the impact of seasonal variations and annual cycles, so that, food shortage can be guaranteed at any time.

Sustainability: Able to maintain long-term sustainability and long-term food supply without damaging the quality life.

Furthermore, according to Soetrisno, there are two options to achieve food security at the national or regional level, namely by achieving food self-sufficiency or attaining food sufficiency. Food self-sufficiency is defined as the fulfillment of food needs which as far as possible comes from domestic supply by minimizing dependence on food trade. Food sufficiency includes global or interregional trade variables. With this concept is demanded the ability to maintain the level of domestic production plus capacity to import to meet the food needs of its population.

Food security and sustainable development: The ecological integrity and value of the rural landscape can be a rural area as a tourist area and a quiet and pleasant living place that can attract investors to invest. Sustainability of development is a continuous improvement of the quality and welfare of the people/residents in which they live and include the availability of various types of adequate and appropriate food. Food security must be seen from the context of improving the quality of life of the people and the environment in the countryside. Pearce and Moran (1994) 
state that sustainable development (sustainable development) has a broader meaning and purpose than sustainable economic growth. Economic, social and economic objectives at a given level can work together. However, on certain conditions in the field, all three can compete and are less supportive.

When this happens, the concept of sustainability leads to the need for a right balance between the three dimensions. The choice of policy needs to be carefully determined by considering each of the interrelated dimensions. Increased food production should be done in ways that sustainability does not diminish and impair the fertility of the soil do not increase erosion and minimize the use of and dependency on natural resources that are not renewable, life support rural communities equitable increasing employment opportunities and provide a life of decent society and prosperity, reduce poverty and malnutrition do not endanger the health of people who work or live on the farm, as well as the health of consumers of agricultural products produced, preserve and improve environmental quality in agriculture and rural areas and always conserve natural resources and biodiversity biological, empower and farmer's independence in decision making land management and farming operation in accordance with its own needs and abilities, utilize and conserve local resources and wisdom of traditional communities in managing natural resources. With a large and growing population, expected the agricultural sector (as a source of and a major provider of food) could meet the food needs of a sizeable and growing in number, diversity and quality (Anonimous, 2006). So that, agricultural development should be directed to the development of sustainable agriculture.

New challenges of food security are more marked by rapid changes in the global environment such as rising volatile petroleum prices increasingly visible climate change and some tendencies or responses from food-producing countries that tend to be more protective. The movement of food prices in 2008 is quite complicated, especially as the prices of some food commodities rose sharply in the first half and fell sharply in the second half. At the beginning of the year, almost everyone was worried about the spike in food commodity prices and had disrupted political stability in some developing countries. Then by the end of the year, people are also restless because the prices of agricultural products tend to plummet. In 2009, food prices rose again slowly but surely, despite not matching the price spike in 2008.

\section{MATERIALS AND METHODS}

This research was describe and analyze the implementation process of Food Security Improvement
Policies in North Bolaang Mongondow regency of North Sulawesi province and the factors that determine the application of the policy of increasing food security in North Bolaang Mongondow regency of North Sulawesi province (Zainal, 2006).

Selection of qualitative approach with case study method and this research was conducted in North Bolaang Mongondow regency of North Sulawesi province, targeting farmer community group as the target of the policy of increasing food security and government bureaucracy apparatus as the implementation of the policy of increasing food security of North Bolaang Mongondow regency. This research uses 2 data sources include. Primary data sources: the data collected from the research informants in this case, the implementation of policy improvement of food security North Bolaang Mongondow regency with in-depth interview technique. Secondary data sources all data and documentation of the research sites relevant to the research focus.

The focus of this study and the discussion description remains oriented from the research problem formulation, namely: implementation of policies to increase food security in North Bolaang Mongondow regency with the description of its focus include: product and food security policy agenda, implementing food security policy. The factors that determine the implementation of the policy of increasing food security North Bolaang Mongondow regency.

\section{RESULTS AND DISCUSSION}

Implementation of policies to increase food security in North Bolaang Mongondow regency: Implementation of policies was determined by the content of the policy and the context of its implementation. The basic idea was that once the policy was transformed, after that policy implementation can be done. Its success is determined by the degree of implementation of the policy. Implementation of the policy undertaken here consists of four policies, namely:

Product and food security policy agenda, food is a basic need for a human to survive. Food sufficiency is a decent human right. The enactment of Law No. 23 of 2014 brought a change to the authority of the administration of government affairs between the government structures. Logical consequences, the region will have priority government affairs according to local character and the needs of local communities. In implementing the product and agenda of food security policy is done through:

Counseling in accordance with the concept of agricultural extension in North Bolaang Mongondow regency defined learning process for the main actors, as 
well as business actors, so that, they would be willing and able to help and organize themselves in accessing market information, technology, capital and other resources in order to increase productivity, business efficiency income and welfare and raising awareness in the preservation of environmental functions. Counseling conducted in North Bolaang Mongondow regency also aims to provide broader knowledge and skills to key actors and business actors in improving their productivity and opinions. Where counseling is done by providing information about the latest programs and technologies to the problems they face.

Education and training, group dynamics, usually used as a strategy to increase awareness, knowledge, skills and attitudes of the client in order to have the ability to solve problems faced. The above concept or theory in practice in North Bolaang Mongondow regency itself is applied in the form of education and training that is by training and field school. First, the training in which the training includes education and training. Education is intended for the deepening of the material, the deepening of theory and the deepening of the procedures in implementing a program or activity. This training is aimed at applying the materials, theories and strategies that can be obtained from education as a form of actual practice simulation.

At School in North Bolaang Mongondow regency own field schools guided by PPL through, Integrated Crop Management Field School (SL-PTT). Through this field school, farmers will get counseling before they implement it in the field, whether it is a program that has been successfully conducted in other areas, as well as the old program but not yet maximal in cultivation. It is apparent that the existence of a field school is a cultural guide for farmers to implement the program.

Implementing food security policy in implementing food security policy in North Bolaang Mongondow regency. Stakeholders involved are Department of Agriculture, Plantation, Forestry and Livestock as a stake holder handling from planning, implementation to supervision. Field agricultural extension (PPL) as a technical officer in the field, accompanying farmers in implementing the planned program, so that, the farming business activity is carried out by the recommendation. Besides it is actively seeking information on agricultural issues and as much as possible can provide solutions. The instructor should also actively participate in training/courses related to the improvement of human resources. In carrying out counseling in each region, each extension officer must arrange/make a schedule of visits to the group at least once a week to meet with farmer groups in addition to conveying information as well as following the development of the crops that are being implemented. Farmer group farmer group, as direct farmers.
Factors that determine the implementation of policies to improve the food security of North Bolaang Mongondow regency

Internal inhibiting factor: The quality of human resources in North Bolaang Mongondow regency was still considered low. There a lot of human resources, especially farmers here have less knowledge, whether it was how to plant and better care. Farming communities here are still many who use the old way in running a farm. In addition to human resources, the lack of agricultural machinery tools is also an inhibiting factor. In North Bolaang Mongondow regency, farm machinery tools are still lacking. Farmers here still find it difficult to run their farming business because it still uses traditional farming tools. It can make the production less good and on the other hand can also reduce their income, considering the results obtained less good.

External barrier factors: In addition to human resources and agricultural equipment, the weather is also influential in running the farm. The weather is erratic, can affect the plants that will or are being planted by farmers. Plants to be planted should see the weather. First, it aims to choose what plants are suitable for planting. It is an obstacle to farmer's community in running their farms. Non-conformity with the current weather types, the production to be produced will also be less in line with expectations. Also, poor agricultural resource capacity also becomes an outer barrier. Agricultural resources in the form of water have a crucial role in agriculture, especially in farming. In North Bolaang Mongondow regency, irrigation is heavily dependent on one springs source, namely Brantas river, this was of course very less because of the many agricultural lands that must be irrigated. Also, the distance to the springs with agricultural land is also quite far away, while the existing irrigation channels were also much damaged.

Internal support factors: The existence of farmer empowerment program is one of the factors that can support the development of agriculture, as well as in North Bolaang Mongondow regency. The empowerment program provided makes the farmers more skilled and knowledgeable and this can affect the farming outcomes to get better as expected to create a food security. Also, the support provided by the regional government helps improve the quality of the farmer's produce. The support provided can be in the form of assistance as well as the knowledge and skills are given to farmers in running a better farming.

External supporting factors: Running the program provided by the government, needed supporting aspects to run well and smoothly. One such aspect, namely the assistance provided by the government to farmers. This 
assistance can ease farmers in running their farms. It helps the farmed enterprises to achieve maximum results where maximum results can also create a food security in the North Bolaang Mongondow regency.

\section{CONCLUSION}

Implementation of policies to increase food security in North Bolaang Mongondow regency: In implementing the product and the agenda of food security policy is done through. Counseling: aims to provide broader knowledge and skills to key actors and business actors in improving their productivity and revenue by offering information on the latest programs and technologies to the problems they face. Education and training, group dynamics in North Bolaang Mongondow regency itself are applied in the form of teaching and training with training and field school. At school in North Bolaang Mongondow regency itself a field school guided by PPL through, Integrated Crop Management Field School (SL-PTT).

Stakeholders involved are Department of Agriculture, Plantation, Forestry and Livestock as a stake holder handling from planning, implementation to supervision. Field agricultural extension (PPL) as the technical officer in the field, accompanying farmers in implementing the planned program, so that, the farming business activity is carried out by the recommendation. Farmer group farmer group as the direct implementer of farming.

Factors that determine the implementation of policies to improve the food security of North Bolaang Mongondow regency

Internal inhibiting factor: The low quality of human resources in North Bolaang Mongondow regency and the lack of agricultural machinery.

External barrier factors: Unpredictable weather and limited capacity of agricultural resources.

Internal support factors: The existence of farmer empowerment program and support from Local Government of North Bolaang Mongondow regency.

External supporting factors: The existence of assistance from the Government of North Bolaang Mongondow regency that can ease the burden of farmers in running their farms.

\section{REFERENCES}

Agus, P. and E. Pasandaran, 1990. [Food Safety: Challenges and Opportunities]. LP3ES Publisher, Jakarta, Indonesia, (In Indonesian).

Anonimous, 1998. [Public policy analysis: Theory and its application]. Faculty of Administrative Sciences, Brawijaya University, Malang, Indonesia. (In Indonesian)
Anonimous, 2006. [Public policy for developing countries]. PT Elex Media Komputindo, Central Jakarta, Jakarta, Indonesia. (In Indonesian)

Charles, O.J., 1996. [Introduction to Public Policy]. PT RajaGrafmdo Persada, Depok, Indonesia, (In Indonesian).

Dreze, J. and S. Amartya, 1989. Hunger and Public Action. Clarendon Press, Oxford, England, ISBN:9780198286349, Pages: 373.

Edwards, G.C., 1980. Implementing Public Policy. CQ Press, Washington, DC., USA., ISBN: 9780871871558, Pages: 181.

FSAMA., 2010. [The strategic plan BKP RI 2010-2014]. Food Security Agency, Ministry of Agriculture, South Jakarta, Indonesia. (In Indonesian)

Hadar, I.A., 2008. [The Fall of Food Security]. Kompas Publishing, Jakarta, Indonesia, (In Indonesian).

Lassa, J., 2009. [Hunger Discrimination and Food Security Indonesia 1958-2008: A Case Study of East Nusa Tenggara, in 50 Years of East Nusa Tenggara Food Pilgrimage]. PT Timor Media Grafika, Kupang, Indonesia, (In Indonesian).

Maxwell, D.G., 1996. Measuring food insecurity: The frequency and severity of coping strategies. Food Policy, 21: 291-303.

Maxwell, S. and M. Smith, 1992. Household food security: A conceptual review. Master Thesis, University of Sussex, Brighton, England.

Meter, D.S.V. and C.E.V. Horn, 1975. The policy implementation process: A conceptual framework. Administration Soc., 6: 445-448.

Nugroho, D.R., 2006. [Public Policy for Developing Countries]. PT Elex Media Komputindo, Jakarta, Indonesia, (In Indonesian).

Pearce, D.W. and D. Moran, 1994. The Economic Value of Biodiversity. Earthscan, London, England, ISBN:1-85383-195-6, Pages: 167.

Smith, N.I., 1994. Down-to-Earth Strategic Planning. Prentice Hall, Upper Saddle River, New Jersey, USA., ISBN:9780724802982, Pages: 137.

Suryana, A., 2002. [Challenges and Policy on Food Security]. In: Community Empowerment to Achieve Food Security and Economic Recovery, Hardinsyah, A. Rahardjo, D. Martianto, M.N. Andrestian (Eds.). Center Of Food and Nutrient Studies UGM, Depok, Indonesia, pp: 1-29 (In Indonesian).

Thomas, R.D., 1987. Understanding Public Policy. Prentice-Hall, Englewood Cliffs, New Jersey, USA., Pages: 338.

Timmer, C.P., 2005. Food security and economic growth: An Asian perspective. Asian Pac. Econ. Lit., 19: 1-17.

Zainal, A.S., 2006. [Public Policy]. Suara Bebas Publisher, Jakarta, Indonesia, (In Indonesian). 